\title{
Some Ideas on Moving a Book Collection
}

\begin{abstract}
Some of the principles are given that can be applied in moving a book collection from one library into another, as well as some of the more obvious pitfalls to be avoided. Questions that may arise and decisions which must be made in planning the move are discussed briefly, including the orientation of the transfer, problems associated with locations, methods of transporting the collection, and materials needed. A few comments on strategy and tactics of the move, as well as some advantages of an internal operation are offered in conclusion.
\end{abstract}

$T$ HERE CAN be no doubt that it can be something of an adventure to move a book collection-out of a crusty old crackerbox of a library into a spacious temple of luxury. Anyone who has ever done it will agree, not because the outgoing library is usually an assault upon sanity, and the in-coming one a set of new and invigorating problems, but because the move itself presents a challenge far removed from the usual professional occupation.

This essay will offer some general observations on moving a book collection, as well as some of the principles that can be applied. It will be no definitive statement, but it may be of some service to those fortunate enough to have to worry about moving into a new building.

Many of the libraries built during the early part of this century apparently were designed for maximum security and minimum access. They were small and crowded, and offered but little refuge to books and less to readers and staff. The point of this brief discourse is not to disparage old libraries, however, but to emphasize a basic point, a rule of book

Mr. Roberts is Chief, Circulation Department, Washington University Libraries, St. Louis. moving, if you will: the difficulties involved in moving a book collection out of an old library are far greater than those of moving it into a new building. A general exodus from a typical old library with narrow aisles, inadequate lighting, small windows, few doors and no elevators make it obvious that such a rule should at least be kept in mind when planning a book move, lest the person responsible find himself at the very outset at a point of no egress.

\section{ARRANGement of Collection}

For reasons that have partly to do with time and economy, but mainly with necessity, the arrangement of the book collection in the old library is seldom the same as it is intended to be in the new. Over the years collections get jammed in wherever they will fit, books go into storage, new shelving is added in strange places, and so on. Although this occurs in virtually every library, it does confront the mover with the necessity of making a crucial decision early in the planning stage. He must decide on one of two methods, although either is open to considerable variation depending on the equipment and manpower available.

The decision involves the orientation of the book transfer. The librarian re- 
sponsible can base his plans on the intended arrangement of the collection in the new library, or on the existing arrangement in the old. He can, for instance, move out of the old building beginning with range one, section one in the top floor. Following this procedure, and assuming the order in which the various classes are to be shelved differs from the existing order, the location of a particular class in the new building must be pre-determined. For example, if the order of shelving in one floor of the old building is G, T, R, B, C, D, E and F (a not unlikely occurrence), and it is intended that classes C, D, E, F and G in that order be on one level of the new building, then, if the mover begins with the first class in the old library, he must know exactly where in the new library class $\mathrm{G}$ is to be shelved, and in order to know this he must know how many sections must be left for classes C, D, E and $\mathrm{F}$, which precede $\mathrm{G}$. The same is true for any other floor in the building. If he has the equipment and manpower he can move from every floor simultaneously; the important point is that he is moving into predetermined locations.

A second choice is to move out of the old building according to the new library shelving sequence, which, in our example, would be C, D, E, and so on. Assuming the exact locations in the new building to be unknown, then $\mathrm{C}$ must be moved before $\mathrm{D}, \mathrm{D}$ before $\mathrm{E}$, and so on for every level in the building. Undoubtedly the greatest disadvantage of this method lies in its inflexibility, a handicap so severe as to exclude it from serious consideration. On the other hand, the first method, that of moving into predetermined locations, offers such great flexibility, as well as such a high degree of exactitude, that it may be recommended as a second rule of book moving.

There is one situation in which this rule is not applicable. Moving a collection of one million volumes into a building with a capacity of one million does not provide sufficient buffer space to permit predetermined locations, primarily because measurements cannot be so exact that one class begins the shelf following the termination of the previous class. In any event, excepting a storage building, it is difficult to imagine a new library with expansion space of less than 5 per cent, which is sufficient to permit predetermined locations.

\section{Determining the Extent of THE COLLECTION}

One of the first steps to be taken in preparing a book move is to determine the extent of the collection. There is no possible way to avoid this, and he who would try courts disaster. The number of volumes in the collection is of no importance; the linear feet of books is of the greatest importance. It may be that there are several possible approaches to this problem, but essentially there are only two basic methods of accomplishing the desired objective, the correct method and the other methods, all of which may be summed up in one terrifying example.

Were we to divide the total number of volumes in the collection by the average number of volumes per linear foot, we would arrive at a figure of the extent of the collection. Thus:

$\frac{500,000 \text { volumes in collection }}{\text { average of } 6.284 \text { volumes/foot }}=$

This is an impressive figure. It is even more impressive when computed separately for each class. It is, one might say, a first step, and done this way it is a first step down the long road to indescribable chaos. One of the most serious mistakes that can be made in planning a move, especially if locations must be predetermined, is to accept the established figure as to the number of books in the collection. While it is not my intention to impugn the reputation of book counters, such figures are usually based on an inaccurate estimate, and become more inaccurate as the years go by. In addition, 
the only method of determining the average number of volumes per linear foot is by a random sample, and the only true way to take a random sample is with a book of random numbers. To do this we must determine the total number of shelves in the book stack; therefore an accurate count of shelves is necessary. Already we have put much labor into this. Then, when we know the total number of shelves, and have our book of random numbers, and have determined the minimum number of shelves to be counted in order to achieve the desired degree of accuracy, we need only count off the designated shelves, obtain the average number of volumes per linear foot, divide, and three months later we may find ourselves tied in a knot that would turn the sword of Alexander. Admittedly, this is an exaggerated account, yet it is an example of what can happen when we assume too much, when we devise elaborate schemes which in the long run are exceedingly time-consuming, and when we risk so much solely to avoid labor which appears on the surface to be onerous, or even unnecessary. I have calculated the extent of a book collection by the random-shelf method and by measuring each and every shelf (not by myself, of course), and it is my considered opinion that comprehensive measuring involves but little more work and results in far greater accuracy than any of the sampling techniques. Assuming the reader to be convinced that measuring is the only sure way, we have only to summarize quickly the technique of measuring. In a crowded book stack it is possible to measure the vacant shelf space, rather than the actual book footage. If we mark off all those sections having $35^{1 / 2}$ inch shelves, seven shelves to a section, a quick calculation tells us that such a section can contain no more than $20 \mathrm{ft}$. $8 \frac{1}{1 / 2}$ inches of books, and, by subtracting the empty shelf space, we arrive at the total feet of books in that section. The actual measuring may be done with a ruler, tape measure, or measured length of string. Of course, if there is considerable variation in section width from area to area, or if sections contain continuously varying numbers of shelves, it may be simpler and quicker to measure the actual book footage.

\section{Problems Associated with Locations}

Every library preparing to move its collection is confronted with a variety of location problems, many of which may be unique to that library. There are problems which very likely are common to all; books must be transferred from departmental libraries, or from storage, into the new building. Occasionally even an entire branch library must be incorporated into the main collection. Rather than attempt to anticipate all problems, the discussion here will be limited to two basic ones.

First and foremost is the problem of books in storage, or in departmental libraries. Ideally, these books will be in long runs, or will comprise an entire subject class. If such is the case, then there is no real problem, for the planning librarian, having measured the linear feet of books in each class, and knowing their specific locations in the new building, is able to determine exactly where the problem books are to be shelved. It matters little whether they are moved before or after the main collection. On the other hand, if, unhappily, the books are not in long runs or single classes, the mover has no alternative but to assign them separate space in the new building (or leave them until later), where they can stay until ready for final shelving. And while this may appear to be an unnecessary waste of space, the librarian in charge would soon learn to his dismay that any attempt to shelve individual books during the moving operation would be a mistake of the first magnitude. The momentum of the entire move could easily be broken by such an attempt.

The second location problem concerns 
only those libraries that segregate their bound periodicals. If it is intended that these periodicals be integrated into the main collection, the obvious time to accomplish this is during the move. The classed titles may be removed from the old library in shelf list order, and shelved by number in the new building. The mover must know where each title is to fit in and how much space to leave for it. To accomplish this a card must be prepared for each giving title, class number, and amount of space to be left. Accordingly, there will be a card for Modern Language Association. Publications (PB 6/M 6-8 shelves), another for Poetry (PS 301/P 6-4 shelves), and so on. When the PB and PS collections are being transferred the crew supervisor in the receiving library will be able to tell from the cards given him where and in what amount space is to be left. The transfer of periodicals in each class obviously must be coordinated with the transfer of books, arriving after the books have been shelved. Although the execution of this method may seem difficult and likely to result in unfortunate consequences, there is in it the subtle advantage that it keeps the supervisor alert and ready for any contingency.

\section{BOXEs AND LABELS}

There are several factors to be considered in selecting the type or types of boxes to be used in transporting the collection. Size, strength, cost, and availability are primary among these. The basic box should be of sufficient size to carry a reasonable number of books, but not so large that it cannot be carried by one man. It should be sturdy enough to permit stacking and must have handles or handgrips; otherwise it will be awkward to handle. Finally, it should be readily available and obtainable in large quantities on short notice. More than one library has discovered that a beer carton is well designed for carrying books. Being $17^{\prime \prime}$ long, $11^{\prime \prime}$ wide, and $10^{\prime \prime}$ high, it will hold an average carrying load with but few problems involving overly long books. Furthermore, it has handgrips and is heavily constructed.

There are other methods of transport which may be desirable or necessary. Book trucks are very good, as a large one will hold the equivalent of about thirteen beer cartons and obviate the trouble and wear of loading and unloading boxes. They can be difficult to get up and down stairs, however; therefore, unless it is the ground level being moved, or unless an elevator is available, their use may be somewhat limited. Oversize volumes call for larger boxes, and rare books obviously require a degree of protection not possible with the ordinary box.

Unless the librarian in charge of the move has an irresistible urge to live dangerously, it is recommended that labels be used to identify boxes, and that these labels offer some indication of box content and not simply a number, for the crews at the receiving end may (and should) be handling boxes from different locations. Therefore, the label should indicate the floor destination of the box, the class of books contained therein, and consecutive label numbers.

\section{Final Plans-Strategy}

The major stack problem in many an old library is one of too little space; in a new library, on the other hand, the problem may be virtually one of too much space. This is not entirely the frivolous problem it may seem, for there are several factors to be considered. One is that in determining locations a little buffer space must be left between classes in order to avoid the possibility of having one class encroach upon the space allotted to the one following it, while a second is that the collection must be distributed in such a manner that shifting in future years will be held to a minimum. These two factors, being purely mechanical, are easily resolved. There is a problem, however, that is not easily resolved, and which can best be posed as a question: how much expansion space 
is to be allotted to each subject class? As the university places more or less emphasis on teaching and research in various subject fields, the library's acquisitions in those subjects will rise or fall. The question must be answered for each subject, in so far as is possible. For the purpose of the moving operation, the problem may be resolved by assigning a basic code (e.g., two feet of books on each shelf) to all subjects, then varying it according to expansion potential and other factors. In addition, periodicals, theses, and other consecutive type materials may be given special consideration. Since both the total stack footage in the new library and the linear feet of books to be moved are known, the librarian can arrange the subject classes in descending order of expansion potential, as best he is able to determine, and then increase the space allocated beginning with those subjects high on the list, as well as those which will soon be absorbing storage, or other books. This process is continued until the total footage of books being moved has been spread throughout the book stack. Buffer space assigned to a class must be included in the space assigned to that class. Finally, a coding system will emerge with code numbers assigned to all classes. An example of such a system is offered below.

Code 1: One foot of books on each of five shelves (in a single-face section): Classes given the highest expansion potential.

Code 2: Two feet on each of five shelves: Classes given a lower expansion potential.

Code 3: Three feet on each of six shelves: Theses and periodicals.

Code 4: Two feet on each of four shelves: Oversize books.

Code 5: One foot on each of three shelves: Classes that must absorb storage books not shelved during the move, anticipated gift collections, and the like.

For reasons that will be clearly understood only when the move is completed, it is important that a logical (and possible) coding system be established and adhered to rigidly during the move. A code helps establish a pattern, a rhythm of shelving, and, even though it may vary from class to class, it remains a catalyst that assists in holding the operation together.

\section{Final Plan-Tactics}

Following the space allocation stage in the planning of the move, an equipment plan of each floor in the new building should be acquired, and on it marked the exact location of every subject class. In addition, an over-all moving plan must be prepared, giving floor, shelving codes and range locations for all classes. Multiple copies of this plan should be available, one for each supervisor, as well as one or two spares. An example of such a plan is given in part below.

\section{Chart I}

Moving schedule-Classes P-PZ, 400-499, 840-869, 890-899. Level 5.

Codes:
P-PM-2
PN-1
PQ-5
PR-1
PS-PZ-2
$400-499-2$
$840-869-2$
$890-899-2$
oversize-4

Space allotted:

Regular size books-1,231 single-face sections

Oversize books- 14 single-face sections

Order of shelving: P-PM, 890-899, 400499, PN-PQ, 840-869, PR-PZ, Oversize

\section{Locations:}

P-PA Begin: Range 1, Section 1 End: Range 5, Section 22

PB-PM Begin: Range 6, Section 1 End: Range 9, Section 4

890-899 Begin: Range 9, Section 7 End: Range 9, Section 12

Direction: North to South 
And so on, throughout the entire level, concluding with oversize books.

As a guide to shelvers, measuring rods should be provided, their length corresponding to the amount of empty space desired on a shelf according to the code in use. Thus, a rod 23/2 inches in length would be used when one foot of books was required per shelf, whereas one only $11 \%$ inches in length would be necessary when the code calling for two feet was in use.

\section{Equipment and Personnel}

Provision of the necessary equipment for the move, including tractors, trailers, lift-gate trucks, and possibly portable elevators and conveyors, as well as the necessary drivers and operators, is a problem in logistics best handled by an agency outside the library, perhaps by the buildings and grounds department of the university. For its part, the library can supply boxes, labels, book trucks, and whatever incidental supplies may be needed.

The library should be prepared to assign as much of its staff to the operation as can be spared and must be able to provide the necessary supervisory personnel. The role of supervisors in the move is of paramount importance. The actual physical labor may be assigned to student assistants, Manpower, Inc., laborers, or to any other reasonably competent group that can be assembled, but, even if an outside firm is hired for the actual moving operation, on-the-job supervision should certainly be undertaken by library personnel, for only they can be expected to realize fully the importance of order and care in moving books.

The volume of manpower involved in the move will depend largely on the number of points from which books are leaving the old building at any one time. This, in turn, is contingent upon the number of supervisors available. Assuming the number of exit points to be constant, the volume of manpower required will increase as the operation progresses, finally leveling off shortly before the midway point is attained. While the actual volume of manpower may vary greatly from library to library, depending upon size, distance to be moved, and other factors, it may be offered as a final rule of book moving, that as much manpower as can be effectively utilized should be employed in order to provide a steadily increasing flow of books into the new library; the flow becoming constant when the shelving crews have attained to their maximum efficiency. This is of primary importance because, although the pace of packing in the old library and shelving in the new increases with experience, a leveling off in packing efficiency begins before a corresponding leveling off in shelving efficiency. As the move progresses, given a fixed number of shelvers, additional workers should be added to the out-going library until packing and shelving are balanced. At that time additional help should be available if needed to maintain the now constant flow, because once the momentum of book flow has been built up, it must not be permitted to falter.

\section{ConCLusion}

There are several benefits to be realized in having the library undertake the move itself. One is that, given adequate planning and supervision, the collection will be transferred in remarkably good order. Furthermore, since there is no question but that moving is hard on books, to a greater or lesser degree depending upon the method used and care exercised, the collection will suffer minimum damage, primarily because those responsible have a personal interest in preventing damage. The greatest advantage, however, is one of cost. Admittedly, the total cost of any book move is diffcult to determine. Planning may begin a year before the operation commences, while during the move quite a few of the library staff may be involved. The sal-

(Continued on page 119) 
TABLE 12

Summary of Data of Writing Activtry by Librarians Given in Average Publications per Author

\begin{tabular}{|c|c|c|c|c|}
\hline & $\begin{array}{c}\text { Library } \\
\text { Seience } \\
\text { Doctorates }\end{array}$ & $\begin{array}{l}\text { Non-Library- } \\
\text { Seience } \\
\text { Doctorates }\end{array}$ & $\begin{array}{l}\text { Librarians with } \\
\text { Master's Theses } \\
\text { Cited }\end{array}$ & $\begin{array}{l}\text { Librarians } \\
\text { Chosen from } \\
\text { Citation in } \\
\text { Library } \\
\text { Literature }\end{array}$ \\
\hline $\begin{array}{l}\text { Number of master's theses } \\
\text { cited } \\
\text { Number of dissertations cited } \\
\text { Number of articles cited } \\
\text { Number of book reviews cited } \\
\text { Number of monographs cited } \\
\text { Total number of publications } \\
\text { cited } \\
\text { Publications cited in years after either } \\
\text { award of degree or first publica- } \\
\text { tion: } \\
\text { First } \\
\text { Second } \\
\text { Third and fourth } \\
\text { Fifth to tenth } \\
\text { After tenth }\end{array}$ & $\begin{array}{c}0.20 \\
0.82 \\
12.30 \\
4.05 \\
1.34 \\
18.60 \\
\text { (median } 8 \text { ) }\end{array}$ & $\begin{array}{c}0.12 \\
0.02 \\
19.30 \\
4.90 \\
2.85 \\
27.0 \\
\text { (median } 13 \text { ) }\end{array}$ & $\begin{array}{c}1.00 \\
0.02 \\
1.15 \\
0.19 \\
0.10 \\
2.44 \\
\text { (median 1) }\end{array}$ & $\begin{array}{c}0.21 \\
0.02 \\
4.86 \\
0.42 \\
0.14 \\
5.70 \\
\text { (median 1) }\end{array}$ \\
\hline
\end{tabular}

obtained their education and experience outside the library environment.

Because of the scope of this study, the significance or area of publications was not considered. It might be of value for a study to relate the reasons for the lack of correlation between the prolific authors holding library science doctorates and the prolific authors of documentation literature.

\section{Conclusions}

Certain patterns of writing habits among librarians can be discerned from the data accumulated for this study. The librarians who obtain doctorates write substantially more than librarians without the degree. To obtain a doctorate means that a person must work diligently, usually beyond the demands made on the average librarian. The selection process perhaps filters the applicants for the doctorate so that only the hard workers and diligent writers are awarded the degree. The doctorate seems to be a difference in writing productivity whether the degree was in library science or in some other field. The citation of the master's thesis in Library Literature does not seem to have any effect on the publication activity after the award of the master's degree. Authors chosen at random from citations in Library Literature produced significantly more publications than the average librarian, but did not compare to the productivity of the doctorate.

\section{MOVING . .}

\section{(Continued from page 108)}

aries of all library personnel taking part must be included in the over-all cost, and the library neglecting to do this deceives only itself. Even so, the cost of hiring a moving company to do the job can be almost astronomical, exceeding by three to five times the cost of an internal operation; because, though recognizing that the library must account for its own staff time, regardless of who actually moves the books, the burden of planning and supervision must by necessity be borne by the library staff. 